\title{
Super Antibiotics, Part I. Hyperforin
}

\author{
Ilia Brondz \\ Norwegian Drug Control and Drug Discovery Institute (NDCDDI), Ski, Norway \\ Email: ilia.brondz@gmail.com
}

How to cite this paper: Brondz, I. (2016)

Super Antibiotics, Part I. Hyperforin. Voice of the Publisher, 2, 19-27.

http://dx.doi.org/10.4236/vp.2016.24004

Received: October 27, 2016

Accepted: December 2, 2016

Published: December 5, 2016

Copyright $\odot 2016$ by author and Scientific Research Publishing Inc. This work is licensed under the Creative Commons Attribution International License (CC BY 4.0).

http://creativecommons.org/licenses/by/4.0/ (c) (i) Open Access

\begin{abstract}
In this series of papers, we will present the appearance of antibiotics in general, from the original animal and microbial natural peptides and proteins, metabolites of molds and yeasts, and bacterial metabolites, to a new generation of plant-based antibiotics. The focus will be on the discovery of hyperforin and its curative properties as a new multitarget antibiotic with unique properties and possibilities for the development of a multitarget medical tool. Chromatography and mass spectrometry of hyperforin, together with its antibiotic, antiprotozoal, and anticancer activities, will be presented in this series. A description of chromatographic/mass spectrometric evidence of the passage of hyperforin through the blood-testis barrier (BTB) and the blood-brain barrier (BBB) will be provided in part II. This antibiotic is a useful tool in the struggle against Neisseria gonorrhea and Neisseria meningitides because of its free passage through the BTB and BBB and its immunomodulatory effects, together with antibacterial and detoxification effects. This paper is the first in a series that addresses the problems of using antibiotics in general and the need for the development of a new generation of antibiotics. The advantages and disadvantages of using antibiotics in human and veterinary medicine will be discussed, as will the possible associated epidemics in general and the epidemics of methicillin-resistant Staphylococcus aureus (MRSA) in particular.
\end{abstract}

\section{Keywords}

Antibiotics, Hyperforin, Super Antibiotic, Fifth Generation Antibiotic, Mass Spectroscopy, Gas Chromatography-Mass Spectrometry, Blood-Testis Barrier, Blood-Brain Barrier, Methicillin-Resistant Staphylococcus aureus (MRSA)

\section{Introduction}

The development of antibiotics is tightly connected to the discovery and existence of microorganisms and their role as infection agents; in other words, the possibility to detect one-celled organisms under microscopic observation, to cultivate them on fast 
media on Petri dishes or in liquid media, to isolate single colonies or individual microorganisms, and to analyze their toxic and useful metabolites.

Even before the understanding and acceptance of the germ theory, attempts to use different remedies from natural sources were performed. Abundant written evidence has been found in manuscripts from ancient Egypt, the Old Testament, Codes from ancient China, and even in archeological findings dating to prehistoric times. The struggle against infectious diseases was also present when the Miasmic doctrine was accepted as being correct.

The appearance of antibiotics provided humankind the possibility to be healthier and live longer; however, the misunderstanding of the almighty power of antibiotics and the ignorance of some government/health administrators may lead large parts of the general population to disaster and even annihilation.

\subsection{At the Beginning}

Before every talk about antibiotics, the discoveries that have provided the possibility of using antibiotics should be presented, and the applications of antibiotics should be explained.

As the beginning of this field of study, Antonie Philips van Leeuwenhoek, a Dutch tradesman who was chamberlain for the sheriffs' assembly chamber in the City Hall of Delft, a scientist, a member of the Royal Society from February 1680, and the recognized father of microbiology, described in 1674 the infusoria and in 1676 the bacteria from the genus Selenomonads. In doing this, he founded the study and knowledge of one-celled organisms, many of which are pathogenic to humans, animals, and plants. One-celled organisms were and continue to be the primary cause of most infectious and many inflammatory diseases.

It should not be forgotten that the book Micrographia had been published in 1665 by the Englishman Robert Hooke, who was born on July 18, 1635. In this book, Hooke first applied the word "cell" to describe the basic unit of life. He investigated plant cells using microscopy, and, in the spirit of modern science, studied and described the structure of cells, which constituted the beginning of histology.

The second step was the germ theory of disease states proposed by Louis Pasteur. Pasteur, born on December 27, 1822, was a French chemist and microbiologist who introduced the modern practices of vaccination, microbial fermentation, and pasteurization. He also introduced the concept of chirality in the field of chemistry. Moreover, he disproved the doctrine of spontaneous generation and proposed the germ theory.

However, the germ theory was predated by Ignác Fülöp Semmelweisa, who was a Hungarian obstetrician born on July 1, 1818 in Buda. Semmelweisa introduced the need for disinfection in obstetric and chirurgical practices. He was murdered by opponents

in the field of obstetrics, Späth, Scanzoni, Siebold, and von Hebra, who also prevented the publication of his articles and book see in [1].

Third came an important observation by Englishman Sir Alexander Fleming, born in August 6, 1881. In 1923, he discovered the bacteriolytic activity of the enzyme lysozyme 
and tried to use it in the struggle against infectious diseases. Fleming later observed and recognized the antagonism of the mold Penicillium notatum (Penicillium chrysogenum, also known as Penicillium notatum) toward staphylococci, which led to the discovery of the first antibiotic substance, penicillin, obtained from the mold Penicillium notatum. The era of antibiotics had begun.

However, at about the same time at which Sir Alexander Fleming discovered the antibacterial action of penicillin, in 1925, André Gratia (1893-1950) published an article [2] in which he described very briefly colicin $\mathrm{V}$ among the class of bacteriocins. Bacteriocins were, in his opinion, a class of antibiotics. Gratia was a microbiologist and virologist of Belgian origin who, in accordance of article [3], was forgotten as being the pioneer of the discovery of bacteriocins (as antibiotics), which were antibacterial peptides of bacterial and viral origin.

The practices of using a natural chemotherapeutic agent, as the substance quinine (from the bark of Cinchona), against infection by the one-celled malaria parasite plasmodium was introduced in Europe by the Jesuit Cardinal John de Lugo, born in 1583 see in [1]. Quinine may have been the first natural plant antibiotic. Hyperforin is also an antibiotic of plant origin.

\subsection{Antibiotics in the Family of Penicillin and Cephalosporin}

Currently, several generations of antibiotics in the family of penicillin and cephalosporin are known: the first generation consists of penicillin $\mathrm{G}$ and penicillin $\mathrm{V}$, the second of ampicillin and amoxicillin, the third of carbenicillin and ticarcillin, and the fourth of mezlocillin sodium and piperacillin.

In addition to penicillin, several other antibiotics that are the products of bacterial fermentation have been used in medical practice, including cephalosporins and tetracyclines, which are the products of mold and bacterial fermentation. In fact, these antibiotics, including modern penicillin, are all half synthetic.

\subsection{Vaccination versus Antibiotics}

Based on observations that it is the cause of the development of bacterial antibiotic resistance, several popular administrative attempts to undermine the use of antibiotics were carried out in the last half century. It was proposed that antibiotics and chemotherapeutics, such as primaquine, be replaced with an antimalarial vaccine. Harm from misuse of antibiotics exists. The careful use of antibiotics by the general population in developed countries is not a cause of bacterial antibiotic resistance, but rather, the misuse of antibiotics in veterinary practice, the poultry industry, and fish farming, as well as misuse by the populations of developing and underdeveloped countries. Therefore, the administrative restriction of the use of antibiotics in the general population is not a solution; rather, their use in veterinary practice, the poultry industry, and fish farming should be restricted, and antibiotic misuse should be prevented through improved information among the populations of developing and underdeveloped countries.

Vaccination has and will continue to play a significant role in the prevention of dis- 
eases. Several infectious situations cannot be cured by antibiotics alone or by antibiotics at all, e.g., rabies, poliomyelitis, and tetanus (lockjaw); in contrast, syphilis, malaria, and MRSAs cannot be prevented or cured by vaccination. Vaccination and immunization by immunoglobulins should not and cannot substitute for the use of antibiotics.

\subsection{Mass Migration, Methicillin-Resistant Staphylococcus aureus (MRSA), Hygiene, and Sanitation}

Mass migration is always triggered by a search for a "better life" by groups of peoples from disastrous territories or areas with limited resources who are looking to gain access to new territories rich in resources. The disastrous territories or areas with limited resources include those characterized by famine, drought, war, mismanagement, joblessness, tyranny or insurgence, or simple territories with a low level of cultural and social life. Such situations are always accompanied by a low level of hygiene and sanitation. A political or economic discussion is not the subject of this paper; rather, here we aim to address the following question: "Can modern mass migration be a threat to native populations (indigenous populations of Europe) as an epidemic disaster, and what must be done to avoid this?"

The disappearance of the native Neanderthal population in Europe can be attributed to infectious diseases that were introduced by newcomers: Homme de Cro-Magnon (Cro-Magnon man). If infections were not the main cause, it is difficult to ignore that they were among the important causes of the disappearance of the Neanderthal population in Europe.

Human migration was a key factor in the global dissemination of malaria [1] [4]. Malaria is believed to have originated in Africa, specifically in Ethiopia [1] [5].

In the fourth century, Attila and his army brought black rats to Europe in their string of carts. In the twelfth century, Genghis Khan and his army brought gray rats to the doorstep of Western Europe in their string of carts. Black and gray rats originated in Asia. From 1346-1353 in Europe, rodents were the main cause of the spread of the most devastating pandemics in human history, the Black Death or Black Plague, which resulted in the death of an estimated 75 - 200 million Europeans.

"The Native Population of the Americas in 1492", presented by William M. Denevan, provides estimates of the population of the pre-contact Americas, which was as high as 112 million in 1492 [6]. It is known that a significant cause of the demise of the North American indigenous population was black pox, which was introduced and deliberately spread among the indigenous population by European migrants. Currently, more than six centuries later, the indigenous population is smaller than it was in 1492 .

In South America, the situation was and is similar to that in North America; however, in South America, indigenous women infected Spanish Conquistadors with syphilis. Syphilis was not known in Europe before the mass return of the Spanish Conquistadors from America to Europe. In the beginning, the disease was even known under the name

of "Spanish illness" [7]. Syphilis was a significant source of harm to fecundity among the European population before the introduction of condoms and antibiotics. Today, 
syphilis remains a serious illness with significant health consequences.

The introduction of Chinese farm workers (working coolies) in the eighteenth century to the Pacific islands resulted in mass death among the indigenous population from tuberculosis, leprosy (caused by Mycobacterium leprae), and diphtheria.

The relatively poor level of medical development in Russia and the continuous migration from Asia since ancient times until before 1925 led to repeated waves of epidemics of black pox, the Plague, cholera, and typhus, which were brought by merchants and migrants from Iran, Afghanistan, India, and China. These epidemics often were spread further to Central and Western Europe. After 1925, the medical services in Soviet Russia were not substantially better, but epidemics were stopped by the use of improved sanitation and frontier cordons. Sanitary cordons and border control were introduced. The people and goods were controlled at customs posts, where documents and certificates were demanded, especially from people and goods from regions that were known to be epidemiologically dangerous. The same was done in many countries in Europe and North America, even before 1925. The high standards of sanitation and hygiene in these countries played a crucial role in breaking down the cycle of epidemics.

In today's EU, there are no customs posts between the member countries, and no travelers, migrants, or goods are subjected to control regarding health issues or biological/infection contamination when they cross national borders between EU member countries. After entering one EU country on a legal or illegal basis, the persons or goods are allowed to cross the borders of all EU member countries without passing through customs or health control. The spread of dangerous insects/vectors, such as lice and fleas, or infectious diseases, such as tuberculosis, HIV, and especially MRSA, are imminent.

Recently, the EU has registered the reintroduction of malaria by migrants [8], and both the EU and the USA have reported the introduction of the Ebola and Zika viruses (seven EU countries reported 80 Zika cases in pregnant women; see more at: http://ecdc.europa.eu/en/healthtopics/zika_virus_infection/zika-outbreak/pages/epide miological-situation.aspx\#sthash.0cxI6MpK.dpuf.

The capacities of hospitals will not be sufficient in the case of an outbreak of MRSA or other epidemics/mass infections triggered by a mass influx of people from places that are the usual habitats of MRSA and other cocci that are multiresistant to antibiotics; the same can be said about antibiotic-resistant tuberculosis, syphilis, gonorrhea, and meningitis, as well as the incurable Ebola and Zika viruses.

The outbreak of MRSA or other epidemics is imminent; the question is not if, but when. The possibility that hospitals, clinics, schools, day care centers, medical consultation facilities, restaurants, food shops, and other social and public vital places will be contaminated with MRSA and other antibiotic-resistant bacteria is real. The present capacity for hospital isolation boxes in relation to the mass influx of migrants as potential carriers of new infections in the USA, Canada, Australia, and the EU remains insufficient. Regarding the isolation of outbreaks of these diseases, the health care units in 
these countries are not prepared in terms of sanitation or medical products, such as new-generation disinfectants and antibiotics capable of fighting MRSA and other antibiotic-resistant bacteria.

Therefore, antibiotics that possess the ability to act against penicillin- and multiantibiotic-resistant bacteria are of great importance, especially if such antibiotics have positive immunomodulation effects and affect the microflora of the lungs of patients with tuberculosis and antibiotics which can pass through the BTB or BBB.

Hyperforin is one such antibiotic, as it can act against penicillin- and multiantibiotic-resistant bacteria, provides immunomodulatory effects, and exhibits the ability to pass through the BTB or BBB [9]-[16].

In the "Antibiotikumet "Hyperforin" og andre innholdsstoffer i drogen Hypricum perforatum L." [9], it was shown that extracts from Hypricum perforatum L. and the substance hyperforin were active against Staphylococcus aureus S.C. (S. aureus subsp. aureus COL, an early methicillin-resistant Staphylococcus aureus), S. aureus 1085 (fluoroquinolone-resistant Staphylococcus aureus), Streptococcus pneumoniae S.P., $S$. pneumoniae type XVIII, S. viridans, Clostridium sporogenes, Bacillus cereus, Corynebacterium hofmannii, Pseudomonas aeruginosa B10 [17], Proteus mirabilis, and Aspergillus fumigatus.

\section{Hyperforin}

Hyperforin is a substance derived from the herb Hypericum perforatum L. The chemical composition of Hypericum perforatum L. was studied in Australia [18], Norway [9], the former Soviet Union [19], and India [20]. Some attempts to use the extracts for medical purposes were done in the former Soviet Union [21], where [22] the structure of the pharmaceutically active substance (PAS) hyperforin was also proposed [22]. Some aspects of the activity of PAS were poorly elaborated in the former USSR, and the absolute configuration of the molecule of hyperforin was questioned by Brondz in 1978. Subsequently, it was decided that the questionable aspects of this molecule should be checked, and that the antibacterial spectrum of hyperforin should be demonstrated. The work was performed as a graduate degree project at the Pharmaceutical Institute of Oslo University in Norway by Brondz. The supervisor of the microbiological part of the work was Prof. O. Clausen, and the supervisor of chemical part of the project was Docent A. J. Aasen. The results were described in [9]. The microbiological activities of hyperforin previously described in the former USSR were supported, and new facts were collected. Among these facts were the activity of hyperforin against penicillin-resistant cocci and the absence of development of antibiotic resistance toward hyperforin by cocci. Moreover, the chemical composition of Hypericum perforatum L. was more precisely demonstrated [23] [24]; immunomodulatory activities were demonstrated later [12]-[16].

The relative structural elucidation of the hyperforin molecule was performed using X-ray crystallography [10]. The results supported the relative stereochemistry that had previously been proposed in the former USSR by Dobrinin et al. However, the absolute 
configuration (absolute stereochemistry), as assessed using X-ray crystallography, exhibited differences [11] from that proposed by Dobrinin et al. The hypothesis of Brondz that some elements in the absolute stereochemistry proposed by Dobrinin et al. were wrong was supported. The absolute stereochemistry proposed by Dobrinin et al. was based on the partial degradation of hyperforin and spectral analysis. Under partial degradation, some chiral centers of hyperforin exhibited a change in configuration.

The correct absolute stereochemistry of hyperforin was described by Brondz et al. [11]. Additional discussion about the absolute stereochemistry of hyperforin will follow in other articles in this series.

\section{Conclusion}

Hyperforin has a broad array of useful properties, including antibiotic activity against multi-antibiotic-resistant microorganisms and the malaria parasite. It is also an immunomodulatory agent with anticancer and antiviral properties, and can be used as supporting medication in patients with tuberculosis. In the next article of this series, we present evidence of the passage of hyperforin through the BTB and BBB [25]. It is of crucial importance to bring hyperforin into pharmaceutical production and introduce it into medical practice.

\section{References}

[1] Brondz, I., Ed. (2011) Historical Overview of Chromatography and Related Techniques in Analysis of Antimalarial Drug Primaquine. Nova Science Publishers, Inc., New York.

[2] Gratia A (1925) Sur un remarquable example d'antagonisme entre deux souches de colibacille. Compt. Rend. Soc. Biol, 93, 1040-1042. Referred from: Gratia, J.P. (2000) Andre Gratia: A Forerunner in Microbial and Viral Genetics. Genetics, 156, 471-476.

http://www.ncbi.nlm.nih.gov/entrez/query.fcgi?cmd=Retrieve\&db=pubmed\&dopt=Abstrac t\&list_uids=11014798"PMID 11014798

[3] Gratia, J.P. (2000) André Gratia: A Forerunner in Microbial and Viral Genetics. Genetics, 156, 471-476.

[4] Schlagenhauf, P. (2001) Chapter I, Travelers' Malaria: Some Historical Perspectives. In: Schlagenhauf-Lawlor, P., Ed., Travelers' Malaria, BC Decker Inc., Hamilton, London, 1-13.

[5] Bruce-Chwatt, L.J. and de Zulueta, J. (1980) The Rise and Fall of Malaria in Europe. Oxford University Press, Oxford.

[6] Denevan, W.M., Ed. (1992) The Native Population of the Americas in 1492. The University of Wisconsin Press, Madison. https://uwpress.wisc.edu/books/0289.htm

[7] Crosby, Jr., A.W. (1969) The Early History of Syphilis: A Reappraisal. American Anthropologist, 71, 218-227.

[8] Monge-Maillo, B. and Lopez-Velez, R. (2012) Migration and Malaria in Europe. Mediterranean Journal of Hematology and Infectious Diseases, 4, e2012014. https://doi.org/10.4084/mjhid.2012.014

[9] Brondz, I. (1979) Antibiotikumet "Hyperforin" og andre innholdsstoffer i drogen Hypricum perforatum L. Thesis (Cand. Pharm.), University of Oslo, Oslo (in Norwegian).

[10] Brondz, I., Greibrokk, T., Groth, P.A. and Aasen, A.J. (1982) The Relative Stereochemistry of Hyperforin-An Antibiotic from Hypericum perforatum L. Tetrahedron Letters, 23, 
1299-1300. https://doi.org/10.1016/S0040-4039(00)87088-4

[11] Brondz, I., Greibrokk, T., Groth, P. and Aasen, A.J. (1983) The Absolute Configuration of Hyperforin, an Antibiotic from Hypericum perforatum L., Based on the Crystal Structure Determination of Its $p$-Bromobenzoate Ester. Acta Chemica Scandinavica, 37A, 263-265. https://doi.org/10.3891/acta.chem.scand.37a-0263

[12] Brondz, I., Lingaas, E., Olsen, I. and Midtvedt, T. (1984) The Influence of Hyperforin on Phagocytosis of Escherichia coli by Human Polymorphonuclear Neutrophils in Vitro. 14th International Symposium on the Chemistry of Natural Products, Poznań, 9-14 July 1984, 590.

[13] Brondz, I. (1986) Lecture Entitled "The Influence of Hyperforin on Phagocytosis of E. coli by Human Polymorphonuclear Neutrophils in Vitro. Norlændska Infektionssjkdomar Symposium, Vårmøteti Sundsvall, 14-15 May 1986, No 4.

https://www.researchgate.net/publication/233795016_The_influence_of_hyperforin_on_ph agocytosis_of_Ecoli_by_human_polymorphonuclear_neutrophils_in_vitro

[14] Brondz, I. (1987) Influence of Hyperforin upon Phagocytic Functions in Human Polymorphonuclear Leucocytes. 4th International Conference on Chemistry and Biotechnology of Biological Active Natural Products, Budapest, 10-14 August 1987, 119.

[15] Brondz, I. (2012) Enhancement of the Immunity in AIDS and Other Immunocompromised Patients by Hyperforin an Antibiotic from Hypericum perforatum L. 2nd ARIP European Conference on Antimicrobial Resistance \& Infection Prevention, Vilnius, 4-5 October 2012, 60.

[16] Brondz, I. and Brondz, A. (2012) Recent Enhancement of the Immunity in AIDS and Other Immunocompromised Patients by Hyperforin an Antibiotic from Hypericum perforatum L. (In Vitro Model) Part I. Journal of Biophysical Chemistry, 3, 304-310. https://doi.org/10.4236/jbpc.2012.34037

[17] Livermore, D.M. (2002) Multiple Mechanisms of Antimicrobial Resistance in Pseudomonas aeruginosa: Our Worst Nightmare? Clinical Infectious Diseases, 34, 634-640. https://doi.org/10.1086/338782

[18] Osborn, E.M. (1943) On the Occurrence of Antibacterial Substances in Green Plants. British Journal of Experimental Pathology, 24, 227-231.

[19] Gurevich, A.I., Dobrynin, V.N., Kolosov, M.N., Popravko, S.A., Ryabova, I.D., Chernov, B.K., Derbentseva, N.A., Aizenman, B.E. and Garagulya, A.D. (1971) Hyperforin, an Antibiotic from Hypericum perforatum L. Antibiotiki Khimioterapi, 16, 510-513.

[20] Vermaa, V., Smelcerovicb, A., Zuehlkeb, S., Hussaina, M.A., Ahmada, S.M., Ziebachc, T., Qazia, G.N. and Spitellerb, M. (2008) Phenolic Constituents and Genetic Profile of Hypericum perforatum L. from India. Biochemical Systematics and Ecology, 36, 201-206. https://doi.org/10.1016/j.bse.2007.09.003

[21] Maksyutina, N.P. and Koget, T.A. (1971) Polyphenols of the Herb Hypericum perforatum and the Preparation Novoimanin. Chemistry of Natural Compounds, 7, 338-341. https://doi.org/10.1007/BF00569009

[22] Bystrov, N.S., Chernov, B.K., Dobrynin, V.N. and Kolosov, M.N. (1975) The Structure of Hyperforin. Tetrahedron Letters, 16, 2791-2794. https://doi.org/10.1016/S0040-4039(00)75241-5

[23] Brondz, I., Greibrokk, T. and Aasen, A.J. (1983) N-Alkanes of Hypericum perforatum: A Revision. Phytochemistry, 22, 295-296. https://doi.org/10.1016/S0031-9422(00)80110-7

[24] Brondz, I., Greibrokk, T. and Aasen, A.J. (1983) N-1-Alkohols of Hypericum perforatum. Journal of Natural Products, 46, 940-941. https://doi.org/10.1021/np50030a025 
[25] Brondz, I. (2016) Super Antibiotics, Part II: Hyperforin, Mass Spectroscopy (MS) and Gas Chromatography-Mass Spectrometry (GC-MS), Evidences of Permeability for Hyperforin of Blood-Testis-Barrier (TBB) and Blood-Brain-Barrier (BBB). International Journal of Analytical Mass Spectrometry and Chromatography, 4 (in Press).

Submit or recommend next manuscript to SCIRP and we will provide best service for you:

Accepting pre-submission inquiries through Email, Facebook, LinkedIn, Twitter, etc. A wide selection of journals (inclusive of 9 subjects, more than 200 journals)

Providing 24-hour high-quality service

User-friendly online submission system

Fair and swift peer-review system

Efficient typesetting and proofreading procedure

Display of the result of downloads and visits, as well as the number of cited articles

Maximum dissemination of your research work

Submit your manuscript at: http://papersubmission.scirp.org/

Or contact vp@scirp.org 